\title{
Selectivity of Organic Products to Trichogramma pretiosum Riley (Hymenoptera: Trichogrammatidae)
}

\author{
JT Amaro ${ }^{1}$, AF Bueno ${ }^{2}$, AF Pomari-Fernandes ${ }^{3}$, PMOJ Neves ${ }^{1}$ \\ 'Depto de Agronomia, Univ Estadual de Londrina-UEL, Londrina, PR, Brasil \\ ${ }^{2}$ Embrapa-Soja, Londrina, PR, Brasil \\ ${ }^{3}$ Univ Federal da Fronteira Sul, Laranjeiras do Sul, PR, Brasil
}

\section{Keywords}

Biocontrol, egg parasitoid, preservation, toxicity

\section{Correspondence \\ JT Amaro, Depto de Agronomia, Univ Estadual de Londrina-UEL, Rod. Celso Garcia Cid, Londrina, PR, Brasil; muchojunio@hotmail.com}

Edited by Moisés Zotti - UFSM

Received 19 August 2014 and accepted 13 July 2015

Published online: 13 August 2015

(C) Sociedade Entomológica do Brasil 2015

\begin{abstract}
The selectivity of various entomopathogens and one insecticide (chlorpyrifos = positive control) to Trichogramma pretiosum Riley (Hymenoptera: Trichogrammatidae) was evaluated in the laboratory, using the protocol established by the Working Group on "Pesticides and Beneficial Organisms" of the IOBC. The evaluated parameters were parasitism (\%), adult emergence (\%), and product repellency to the parasitoid when sprayed on host eggs prior to parasitism (free-choice and no-choice tests). Most of the studied entomopathogens (Bacillus thuringiensis var. kurstaki, Bacillus thuringiensis var. aizawai, Beauveria bassiana, Metarhizium anisopliae, and Trichoderma harzianum) had no effects on biological parameters and were classified as harmless to T. pretiosum. Emergence of parasitoids (progeny viability) was reduced, but remained above $90 \%$, when host eggs were sprayed with Baculovirus anticarsia prior to parasitism in the freechoice test, and B. anticarsia was therefore considered harmless. Chlorpyrifos (positive control) caused high adult parasitoid mortality in all bioassays. While $T$. pretiosum and the tested entomopathogens may be used simultaneously in integrated pest management programs, the use of chlorpyrifos should be avoided.
\end{abstract}

\section{Introduction}

Egg parasitoids of the genus Trichogramma are used as biological control agents in agriculture worldwide due to the simplicity of production and their efficient control of pests (Parra \& Zucchi 2004). They have been used in Latin America to fight pests which damage crops such as cotton, sorghum, soybean, and sugarcane. In Mexico, for example, about 1.5 million hectares is treated with Trichogramma spp. They have also been applied to large areas of Colombia and Cuba but limited in other Latin American countries partially due to the lack of selective pesticides that ensure their preservation (Van Lenteren \& Bueno 2003). It is important to emphasize that Trichogramma is a biological control agent primarily of eggs of lepidopterans, but as agroecosystems are represented by a number of different pests and that damage can still be induced by immatures escaping egg parasitization, the use of integrated strategies for efficient pest control is still mandatory (Monnerat et al 2007).

The spraying of synthetic insecticides is the most common control method for Lepidoptera management in agriculture worldwide. It may have various unwanted effects on the agroecosystem and may reduce or disable biological control by egg parasitoids (Bueno et al 2011). However, a combination of various control methods within integrated pest management is possible and has been recommended. The integration of different control methods in sustainable agriculture allows the suppression of agricultural pest populations below the threshold of economic damage, thereby preserving the environment and benefiting beneficial arthropods (Van Lenteren \& Bueno 2003). 
Entomopathogens are another control method that may be used in the management of various agricultural pests (Magalhães et al 1998). Entomopathogens of agricultural importance include Baculovirus anticarsia (AgMNPV), sprayed to control the velvetbean caterpillar Anticarsia gemmatalis Hübner (Lepidoptera: Eribidae) in soybean (HoffmannCampo et al 2003); Bacillus thuringiensis, which causes mortality in more than 1000 species of insects from various orders (Glare \& O'Callaghan 2000); the fungus Beauveria bassiana, which has a wide geographic distribution and causes disease in orders including Lepidoptera, Coleoptera, Hemiptera, Diptera, Hymenoptera, and Orthoptera (Alves 1998); Metarhizium anisopliae, one of the most important species of entomopathogenic fungi that may infect more than 300 species of insects from various orders (Alves 1998); and Trichoderma harzianum, a necrotrophic microorganism that is effective in controlling some phytopathogenic fungi (Melo 1998), but that may also have adverse effects on insects as previously reported for Myzus persicae Sulzer (Homoptera: Aphididae) (Ganassi et al 2009), Spodoptera littoralis Boisduval (Lepidoptera: Noctuidae) (El-Katatny 2010), and Gryllotalpa gryllotalpa L. (Orthoptera: Gryllotalpidae) (Veena-Bhamrah 2007).

Notwithstanding the efficiency of these entomopathogens, they may also negatively impact the performance and/or efficiency of egg parasitoids, or even infect them directly (Magalhães et al 1998). Therefore, selectivity is crucial for a harmonious integration of these different management tools in integrated pest management (IPM) approaches aimed at reducing the population of harmful insects with the fewest possible changes in other components of the agroecosystem and the environment in general. Therefore, only insecticides with some degree of selectivity may be used together with other adopted IPM methods (Van Den Bosch et al 1982), including biological control by Trichogramma pretiosum Riley (Hymenoptera: Trichogrammatidae).

Thus, selectivity and/or possible harmful nontarget effects of entomopathogens on the efficiency of egg parasitoids must be taken into account when defining the best biological control strategies. In this context, our study aimed to assess the selectivity of different entomopathogens to the egg parasitoid T. pretiosum. Four different bioassays were performed to study pesticide effects when applied on host eggs before and after parasitism with the aim to analyze the direct effects as well as possible repellence to parasitism, triggered by entomopathogens.

\section{Material and Methods}

Four different bioassays were conducted in the laboratory to assess the impact of different entomopathogens (Table 1) on pupae and adults of $T$. pretiosum, as well on parasitization of treated host eggs under free-choice and no-choice conditions. Trials were carried out under controlled conditions $\left(25 \pm 2{ }^{\circ} \mathrm{C} ; 70 \pm 10 \% \mathrm{RH} ; 14 \mathrm{~L}: 10 \mathrm{D} \mathrm{h}\right.$ photoperiod) with five replicates in a completely randomized design, in accordance with the protocols proposed by the "International Organization for Biological Control" (IOBC) (Hassan 1992, Hassan et al 1985, Manzoni et al 2007). Each replicate consisted of a cage with more than 200 adults for which all evaluations were performed.

\section{Parasitoid and host colonies}

Eggs of Anagasta kuehniella (Zeller) (Lepidoptera: Pyralidae) used as hosts and specimens of the egg parasitoid Tg. pretiosum were obtained from insect colonies of Embrapa Soybean (Brazilian Agricultural Research CorporationSoybean), where they had been reared according to Parra (1997) for nearly 6 years.

\section{Bioassay 1: impact of pupal exposure to entomopathogens}

The selectivity of entomopathogens to $T$. pretiosum pupae was tested according to the standard protocols established by the IOBC (Hassan 1992, Hassan et al 1995, Manzoni et al 2007). Briefly, $3-\mathrm{cm}^{2}$ cards (1 card per replicate) holding approximately 500 o-24-h-old eggs of $A$. kuehniella were exposed to newly emerged (o-24-h-old females), mated $T$. pretiosum females. Parasitization was allowed for $24 \mathrm{~h}$. Subsequently, the cards were transferred to vials and kept under controlled conditions until parasitoid pupation, as indicated by the darkening of the host egg (nearly $192 \mathrm{~h}$ after parasitization) (Cônsoli et al 1999). Parasitized host egg containing the parasitoid pupae was then sprayed with solutions of the different entomopathogens tested (Table 1) as specified in Manzoni et al (2007). Treatment with chlorpyrifos was chosen as the positive control according to Bueno et al (2008).

Egg spraying was performed using a Potter spray tower calibrated to deposit a volume to correspond to $1.25 \pm$ $0.25 \mathrm{mg} \mathrm{cm}^{-2}$, in accordance with the norms established by the IOBC (Hassan 1992, Hassan et al 1995, Manzoni et al 2007). This volume was controlled by weighing the cards with the parasitoid pupae before and after the application of treatments. The sprayed eggs with $\mathrm{Tg}$. pretiosum pupae were kept at $25 \pm 2{ }^{\circ} \mathrm{C}$ and $70 \pm 10 \% \mathrm{RH}$ for approximately $2 \mathrm{~h}$ to remove excessive moisture. Subsequently, the treated cards were placed into cages made of glass plates $(13 \times 13 \mathrm{~cm})$ prepared according to the method proposed by Hassan (1992) where they remained until the emergence of adults, which were then fed with honey. 
Table 1 Commercial products and commercial doses evaluated for selectivity to the egg parasitoid Trichogramma pretiosum under controlled laboratory conditions.

\begin{tabular}{llll}
\hline Commercial product (c.p.) & Formulation & Active ingredient (a.i.) & a.i. $100 \mathrm{~L}^{-1} \mathrm{H}_{2} \mathrm{O}$ \\
\hline Water & - & Distilled water & - \\
Baculovirus AEE $^{\circledast}$ & $0.6 \mathrm{WP}$ & AgMNPV & $1.4 \times 10^{11} \mathrm{PIB}$ \\
Thuricide $^{\circledR}$ & $3.2 \mathrm{WP}$ & Bacillus thuringiensis var. kurstaki & $9.6 \times 10^{9} \mathrm{IU}$ \\
Agree $^{\circledR}$ & $50 \mathrm{WP}$ & Bacillus thuringiensis var. aizawai & $5 \times 10^{9} \mathrm{IU}$ \\
Dipel $^{\circledR}$ & $3.2 \mathrm{WP}$ & Bacillus thuringiensis var. kurstaki & $6.2 \times 10^{9} \mathrm{IU}$ \\
Boveril $^{\circledR}$ & $5 \mathrm{WP}$ & Beauveria bassiana & $1 \times 10^{13} \mathrm{conidia}^{12}$ \\
Metarril $^{\circledR}$ & $5 \mathrm{WP}$ & Metarhizium anisopliae & $1.6 \times 10^{12}$ conidia \\
Trichodermil $^{\circledR}$ & $48 \mathrm{SC}$ & Trichoderma harzianum & $5 \times 10^{12}$ conidia \\
Lorsban $^{\circledR}$ & $480 \mathrm{EC}$ & Chlorpyrifos & $240 \mathrm{~g}$ \\
\hline
\end{tabular}

PIB polyhedral inclusion bodies, IU international units, WP wettable powder.
After adult emergence, cards containing approximately $200 \mathrm{~A}$. kuehniella eggs (less than $24 \mathrm{~h}$ after oviposition) were introduced into the cages (one card on the first day and a second card on the fifth day). A drop of honey was provided to the parasitoids on the first and the fifth day after the emergence of adults. Both cards remained in the cages for 6 days after adult emergence (one card remained for 5 days and the other for 1 day). On the sixth day after adult emergence, both cards were removed and stored in air-filled plastic bags under controlled conditions $\left(25 \pm 2^{\circ} \mathrm{C} ; 70 \pm 0 \% \mathrm{RH}\right.$; 14L:10D $\mathrm{h}$ photoperiod) until assessment of the parasitoid biological parameters. Parasitoid host egg ratio used (1 female per 40 host eggs) results in egg parasitization in between 80 and $100 \%$ in the control treatment (water), essential to evaluate the impact of the pesticide on the parasitoid (Hassan et al 1985).

Adult emergence from sprayed parasitized host eggs was calculated by dividing the number of $A$. kuehnilla eggs with emerged parasitoid adults by the total number of parasitized eggs, multiplied by 100 . The parasitization capacity of the $F_{0}$ generation (adults originating from treated eggs containing the parasitoid at the pupal stage) and the transgenerational effects on the percentage of emergence of the $F_{1}$ generation (progeny of the treated generation) were determined using a stereomicroscope.

\section{Bioassay 2: impact of adult exposure to the dry residue} of entomopathogens

Duran tubes (emergence vials, $0.6 \mathrm{~cm}$ diameter $\times 6 \mathrm{~cm}$ height) containing a droplet of honey and approximately 200 A. kuehniella eggs parasitized by newly emerged, mated $T$. pretiosum females were sealed with a plastic film and stored under controlled conditions $\left(25 \pm 2^{\circ} \mathrm{C} ; 70\right.$ $\pm 10 \% \mathrm{RH} ; 14 \mathrm{~L}: 10 \mathrm{D} \mathrm{h}$ photoperiod) until parasitoids emerged. After emergence, the glass plates $(13 \times 13 \mathrm{~cm})$ used to make the cages were sprayed with suspensions of entomopathogens (a single entomopathogen per treatment, Table 1), using the Potter spray tower set to deposit a suspension volume to correspond to $1.25 \pm$ $0.25 \mathrm{mg} \mathrm{cm}^{-2}$. Following the application, plates were dried for $2 \mathrm{~h}$ at $25 \pm 2^{\circ} \mathrm{C}$ and $70 \pm 10 \% \mathrm{RH}$ and subsequently fixed in aluminum frames in a flow of circulating air according to the method proposed by Hassan (1992). In the next step, 200 parasitoids were released into the cages with the treated glass plates (Hassan 1992).

Cards containing A. kuehniella eggs (approximately 200 eggs, less than $24 \mathrm{~h}$ after oviposition) with trickles of honey were provided 1 and 5 days after the release of adults into the cages. Both cards were removed 6 days after adult emergence (see also bioassay 1), placed in transparent air-filled plastic bags and stored under the controlled conditions earlier mentioned until the emergence of parasitoids for the subsequent evaluation of parasitism and progeny viability, as described in bioassay 1 .

\section{Bioassay 3: impact of host egg exposure} to entomopathogens on parasitism by T. pretiosum (free-choice test)

Cards $\left(3 \mathrm{~cm}^{2}\right)$ holding approximately 200 A. kuehniella eggs (less than $24 \mathrm{~h}$ after oviposition) were sprayed with entomopathogens as earlier described. Subsequently, individual cards with treated eggs were introduced into the cages using circulating airflow as proposed by Hassan (1992). Each cage was supplied with a card sprayed with a single entomopathogen and a card sprayed with water (control card), placed next to each other, and exposed to approximately 300 parasitoids (newly emerged, mated $T$. pretiosum). On the fifth day after the start of the bioassay, a second card with the same amount of eggs and recently sprayed with the same products was introduced into the test cage. Both cards were removed on the sixth day (see also bioassays 1 and 2) and stored for later evaluation as before (bioassay 1). 
Bioassay 4: impact of host egg exposure to entomopathogens on parasitism by T. pretiosum (no-choice test)

No-choice tests were carried as in bioassay 3 with the exception that parasitoids were exposed to a single treatment in each cage.

\section{Statistical analysis}

Data obtained were subjected to exploratory analysis to evaluate normality assumptions for the residuals (Shapiro \& Wilk 1965), homogeneity of variance between treatments (Burr \& Foster 1972), and additivity of the model in order to be subjected to analysis of variance (ANOVA). Data not following normality assumptions or homogeneity of variance were transformed. Data on adult emergence (\%) from treatments in which the egg host containing the parasitoid pupae was sprayed were arcsine $\sqrt{X / 100}$ transformed before ANOVA. Means were compared using Tukey's HSD test (5\% error probability) implemented in SAS (SAS Institute 2001).

In addition, the effect of each pesticide on $T$. pretiosum was determined by comparison with a negative control (distilled water) and calculated using the formula proposed by Hassan et al (1985): $\mathrm{E} \%=(1-$ Parasitism in the treatment $/$ Parasitism in the control $) \times 100$ for adult assays and $\mathrm{EP} \%=(1$ -Adult emergence from sprayed pupae/Adult emergence from pupae treated with the control) $\times 100$ for pupa assays. Treatments were classified as follows: class $1=$ harmless $(E / E P<30 \%)$, class $2=$ slightly harmful $(30 \% \leq E / E P<80)$, class $3=$ moderately harmful $(80 \% \leq E / E P<99)$, and class $4=$ harmful $(E / E P \geq 99 \%)$.

\section{Results}

Bioassay 1: impact of pupal exposure to entomopathogens

The entomopathogens applied to host eggs containing $T$. pretiosum pupae inside had no effect on parasitoid emergence. Furthermore, parasitism and progeny viability of $F_{1}$ individuals sprayed as pupae with entomopathogens did not differ between treatments and control (water) on any evaluated day (Table 2). Therefore, all tested entomopathogens (Table 3 ) were classified as harmless (class 1, Hassan et al 1985) to the pupal stage of parasitoid development. Only chlorpyrifos (positive control) negatively affected parasitism and adult emergence with significant differences to the control and other treatments (Table 2). Therefore, this chemical was classified as moderately harmful (class 3 ) or harmful (class 4 ) to T. pretiosum pupae (Hassan 1985) (Table 3).
Bioassay 2: impact of adult exposure to the dry residue of entomopathogens

Parasitism and progeny viability of $T$. pretiosum on A. kuehniella eggs were assessed on the first and fifth days after the emergence of adults exposed to treatments by walking on the sprayed surface. None of the entomopathogen treatments differed from the control (Table 4) and, therefore, were all classified as harmless (class 1, Hassan 1985) on both evaluation days and for both variables analyzed (Table 3). Furthermore, parasitism did not occur in the chlorpyrifos treatment (positive control) at both periods analyzed (Table 2) as a consequence of the high mortality of adults caused by the insecticide. Therefore, this chemical was classified as harmful (class 4, Hassan 1985) (Table 3).

Bioassay 3: impact of host egg exposure to entomopathogens on parasitism by T. pretiosum (free-choice test)

When $T$. pretiosum adults were allowed to choose between cards sprayed either with a treatment or with water, we detected a significantly lower progeny viability (91.8\%) on the first day after spraying (Table 5) only in the treatment with AgMNPV at $1.4 \times 10^{11}$ polyhedral inclusion bodies (PIB). However, since this value (91.8\%) was still higher than $90 \%$, it can be considered satisfactory (Navarro 1998). Progeny viability and parasitism did not differ between the other evaluated entomopathogens and their controls (Table 5). Considering that the entomopathogens did not affect the parasitoid's choice of host eggs, they were all classified as harmless (class 1, Hassan 1985) (Table 3). Similar to the results of bioassays 1 and 2, when host eggs were treated with chlorpyrifos (positive control), the levels of parasitism and progeny viability were significantly lower than in the controls (Table 5) due to the high mortality of both adults and larvae caused by the insecticide. They were thus classified as moderately harmful (class 3, Hassan 1985) (Table 3).

Bioassay 4: impact of host egg exposure to entomopathogens on parasitism by T. pretiosum (no-choice test)

Parasitism by $T$. pretiosum was also evaluated in no-choice tests in which cards sprayed with each treatment (Table 1) were placed in separate cages. Progeny viability and parasitism did not differ significantly between the entomopathogens and control in the no-choice test on the first and fifth days after spraying (Table 6). According to these results, tested entomopathogens were classified as harmless (class 1), as in the free-choice test (Hassan 1985) (Table 3). Only chlorpyrifos (positive control) reduced 
Table 2 Effects of exposure of parasitized host eggs at the pupal stage (bioassay 1) to entomopathogens on Trichogramma pretiosum emergence (\%) and on the parasitism (\%) and progeny survival (\%) of adults emerged from exposed eggs at 1 and 5 days after emergence (DAE).

\begin{tabular}{|c|c|c|c|c|c|}
\hline \multirow{2}{*}{$\begin{array}{l}\text { Treatment } \\
\text { a.i. } 100 \mathrm{~L}^{-1} \mathrm{H}_{2} \mathrm{O}\end{array}$} & \multirow{2}{*}{$\begin{array}{l}\text { Sprayed pupae } \\
\text { Adult emergence (\%) }\end{array}$} & \multicolumn{2}{|l|}{$1 \mathrm{DAE}^{\mathrm{a}}$} & \multicolumn{2}{|l|}{$5 \mathrm{DAE}^{\mathrm{a}}$} \\
\hline & & Parasitism (\%) & Progeny viability (\%) & Parasitism (\%) & Progeny viability (\%) \\
\hline Water & $92.54 \pm 1.11 \mathrm{a}^{\mathrm{b}}$ & $87.91 \pm 2.10 \mathrm{a}$ & $97.64 \pm 1.70 \mathrm{a}$ & $84.10 \pm 2.06 \mathrm{a}$ & $97.56 \pm 0.86 a$ \\
\hline AgMNPV $1.4 \times 10^{11} \mathrm{PIB}$ & $92.87 \pm 1.10 \mathrm{a}$ & $89.74 \pm 1.55 \mathrm{a}$ & $96.48 \pm 1.34 \mathrm{a}$ & $85.35 \pm 2.58 \mathrm{a}$ & $95.80 \pm 0.94 a$ \\
\hline B. thuringiensis var. kurstaki $9.6 \times 10^{9}$ IU & $94.26 \pm 0.72 \mathrm{a}$ & $88.22 \pm 2.90 \mathrm{a}$ & $96.57 \pm 0.23 \mathrm{a}$ & $91.02 \pm 2.02 \mathrm{a}$ & $96.80 \pm 0.80 \mathrm{a}$ \\
\hline B. thuringiensis var. aizawai $5 \times 10^{9} \mathrm{IU}$ & $94.21 \pm 1.40 \mathrm{a}$ & $87.48 \pm 3.85 a$ & $94.45 \pm 0.47 a$ & $88.28 \pm 3.02 \mathrm{a}$ & $95.92 \pm 1.86$ a \\
\hline B. thuringiensis var. kurstaki $6.2 \times 10^{9} \mathrm{IU}$ & $92.83 \pm 0.47 a$ & $88.67 \pm 2.90 \mathrm{a}$ & $96.93 \pm 1.27$ a & $87.03 \pm 1.35$ a & $97.10 \pm 0.83 a$ \\
\hline B. bassiana $1 \times 10^{13}$ conidia & $93.13 \pm 1.60$ a & $92.95 \pm 2.56 \mathrm{a}$ & $96.67 \pm 0.58$ a & $80.60 \pm 4.63 a$ & $95.80 \pm 1.43 a$ \\
\hline M. anisopliae $1.6 \times 10^{12}$ conidia & $94.64 \pm 1.30 \mathrm{a}$ & $86.32 \pm 4.57 \mathrm{a}$ & $96.52 \pm 1.05$ a & $87.81 \pm 3.15 a$ & $95.63 \pm 1.13 a$ \\
\hline T. harzianum $5 \times 10^{12}$ conidia & $95.31 \pm 1.30 \mathrm{a}$ & $85.05 \pm 3.17 a$ & $96.80 \pm 0.98 \mathrm{a}$ & $85.04 \pm 5.44$ a & $93.21 \pm 2.66 \mathrm{a}$ \\
\hline Chlorpyrifos $240 \mathrm{~g}$ & $8.10 \pm 3.03 b$ & $0.00 \pm 0.00 \mathrm{~b}$ & - & $0.00 \pm 0.00 \mathrm{~b}$ & - \\
\hline CV (\%) & 5.49 & 8.29 & 2.45 & 8.74 & 3.37 \\
\hline$F$ & 140.35 & 102.85 & 0.75 & 93.11 & 0.84 \\
\hline$P$ & $<0.0001$ & $<0.0001$ & 0.6361 & $<0.0001$ & 0.56 \\
\hline$D F_{\text {residual }}$ & 36 & 36 & 32 & 35 & 31 \\
\hline
\end{tabular}

CV coefficient of variation

${ }^{a}$ Means \pm standard error of means (SEM) in each column followed by the same letter did not differ from each other according to the Tukey test ( $5 \%$ probability).

${ }^{\mathrm{b}}$ The original analyses were followed by analyses performed using arcsine $\sqrt{X / 100}$ transformed data.

parasitism to $0 \%$ and was therefore classified as harmful (class 4, Hassan 1985) (Table 3).

\section{Discussion}

Emergence of $T$. pretiosum adults was not affected by exposure of parasitized hosts with the parasitoid at the pupal stage to the different entomopathogens tested (Table 1, bioassay 1), different to what has been reported by others for entomopathogens such as $B$. bassiana and M. anisopliae (Samuels et al 2002, Rampelotti et al 2007). The absence of an effect of entomopathogens on T. pretiosum pupae in our study may have resulted from the short time period ( $24 \mathrm{~h})$ between exposure to entomopathogens and parasitoid adult emergence, since the time required for fungi germination is at least $12 \mathrm{~h}$ for deuteromycetes, $18 \mathrm{~h}$ for $B$. bassiana, and $16 \mathrm{~h}$ for M. anisopliae (Alves 1998, Lomer et al 2001). Colonization requires additional time for appressorium formation and their penetration into the eggs (Alves 1998), which together with germination time might be surpassing the time period of $24 \mathrm{~h}$ between parasitoid pupal exposure and $T$. pretiosum adult emergence. This short time tested was important to evaluate any possible negative impact of entomopathogens on pupae, which is usually massive released close to the last $24 \mathrm{~h}$ before adult emergence. However, a negative effect of these entomopathogens on parasitism by $T$. pretiosum might be observed when entomopathogens are applied to parasitized host eggs at earlier stages of parasitoid development (natural occurrence), allowing enough time for infection and fungal appressorium formation and penetration into the infected egg, possibly killing any parasitoid developing inside that egg. Therefore, pupae (less than $24 \mathrm{~h}$ of adult emergence) and entomopathogens can be simultaneously used as applied biological control in IPM.

The parasitization capacity of females emerged from exposure of host eggs at their pupal stage may be reduced directly by pupae mortality or indirectly by adult-induced physiological and behavioral responses (Carmo et al 2010). However, the products did not cause a sufficient reduction of the $T$. pretiosum population required to trigger a reduction in parasitism, probably because there was not enough time for fungi to infect host eggs. Each Trichogramma sp. female may parasitize 20 to 120 eggs, depending on the host (Pinto 1997), which helps to explain the high parasitism observed in the $F_{1}$ generation.

Unlike fungi, viruses and bacteria must be ingested to have any effect on insects (Castro et al 1999, Copping \& Menn 2000). Trichogramma pretiosum adults may ingest viruses or bacteria sprayed onto the host egg during emergence as the adult chews the host egg chorion on its way out. However, the failure to observe any lethal effects of the applied viruses and bacteria on the 
Table 3 Classification of entomopathogen selectivity to Trichogramma pretiosum according to the "International Organization for Biological Control" (IOBC) in different bioassays and 6 days after emergence (DAE) of adults or days after spraying (DAS).

\begin{tabular}{|c|c|c|c|c|c|c|c|c|c|c|}
\hline \multirow{3}{*}{$\begin{array}{l}\text { Treatment } \\
\text { a.i. } 100 \mathrm{~L}^{-1} \mathrm{H}_{2} \mathrm{O}\end{array}$} & \multirow{2}{*}{\multicolumn{2}{|c|}{ Pupae }} & \multicolumn{8}{|c|}{ DAE/DAS } \\
\hline & & & \multicolumn{2}{|l|}{1} & \multicolumn{2}{|l|}{5} & \multicolumn{2}{|l|}{1} & \multicolumn{2}{|l|}{5} \\
\hline & $E P^{a}$ & $c^{b}$ & $\mathrm{E}^{\mathrm{c}}$ & $\mathrm{C}$ & $\mathrm{E}$ & C & $\mathrm{E}$ & C & $\mathrm{E}$ & 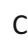 \\
\hline & \multicolumn{6}{|c|}{ Bioassay $1^{\mathrm{d}}$} & \multicolumn{3}{|c|}{ Bioassay $2^{d}$} & \\
\hline AgMNPV $1.4 \times 10^{11} \mathrm{PIB}$ & 0.4 & 1 & o & 1 & 0 & 1 & o & 1 & 4.8 & 1 \\
\hline B. thuringiensis var. kurstaki $9.6 \times 10^{9} \mathrm{IU}$ & 1.8 & 1 & o & 1 & o & 1 & 1.3 & 1 & 6.3 & 1 \\
\hline B. thuringiensis var. aizawai $5 \times 10^{9} \mathrm{IU}$ & 1.8 & 1 & 0.5 & 1 & 0 & 1 & 0 & 1 & 5.3 & 1 \\
\hline B. thuringiensis var. kurstaki $6.2 \times 10^{9} \mathrm{IU}$ & 0.3 & 1 & 0 & 1 & 0 & 1 & 3.5 & 1 & 6.3 & 1 \\
\hline B. bassiana $1 \times 10^{13}$ conidia & 0.6 & 1 & o & 1 & 4.2 & 1 & o & 1 & 8.8 & . \\
\hline M. anisopliae $1.6 \times 10^{12}$ conidia & 2.3 & 1 & 1.8 & 1 & o & 1 & 2.5 & 1 & 6.1 & 1 \\
\hline T. harzianum $5 \times 10^{12}$ conidia & 3.0 & 1 & 3.2 & 1 & 0 & 1 & 1.8 & 1 & 10.3 & 1 \\
\hline \multirow[t]{2}{*}{ Chlorpyrifos $240 \mathrm{~g}$} & 91.3 & 3 & 100 & 4 & 100 & 4 & 100 & 4 & 100 & 4 \\
\hline & - & - & \multicolumn{4}{|c|}{ Bioassay $3^{\mathrm{e}}$} & \multicolumn{3}{|c|}{ Bioassay $4^{\mathrm{e}}$} & \\
\hline AgMNPV $1.4 \times 10^{11} \mathrm{PIB}$ & - & - & 1.9 & 1 & 12.9 & 1 & 5 & 1 & 25 & 1 \\
\hline B. thuringiensis var. kurstaki $9.6 \times 10^{9} \mathrm{IU}$ & - & - & 2.4 & 1 & 6.8 & 1 & 0 & 1 & 6 & 1 \\
\hline B. thuringiensis var. aizawai $5 \times 10^{9} \mathrm{IU}$ & - & - & 2.4 & 1 & 1.9 & 1 & 4 & 1 & 0 & 1 \\
\hline B. thuringiensis var. kurstaki $6.2 \times 10^{9} \mathrm{IU}$ & - & - & 0.0 & 1 & 9.2 & 1 & 0 & 1 & 77 & 2 \\
\hline B. bassiana $1 \times 10^{13}$ conidia & - & - & 0.1 & 1 & 0.0 & 1 & 0 & 1 & 0 & 1 \\
\hline M. anisopliae $1.6 \times 10^{12}$ conidia & - & - & 4.4 & 1 & 0.9 & 1 & 0 & 1 & 0 & 1 \\
\hline T. harzianum $5 \times 10^{12}$ conidia & - & - & 2.7 & 1 & 3.9 & 1 & 0 & 1 & 0 & 1 \\
\hline Chlorpyrifos $240 \mathrm{~g}$ & - & - & 97.8 & 3 & - & - & 100 & 4 & 100 & 4 \\
\hline
\end{tabular}

${ }^{\mathrm{a}}$ EP (Percent of reduction of adult emergence) $=(1-$ Treatment adult emergence/Control adult emergence $\left.) \times 100\right)$.

${ }^{\mathrm{b}}$ Classification: class $1=$ harmless $(\mathrm{E} / \mathrm{EP}<30 \%)$, class $2=$ slightly harmful $(30 \% \leq \mathrm{E} / \mathrm{EP}<80)$, class $3=$ moderately harmful $(80 \% \leq \mathrm{E} / \mathrm{EP}<99)$, and class $4=$ harmful $(E / E P \geq 99 \%)$.

${ }^{\mathrm{C}} \mathrm{E}$ (Percentage of reduction of parasitism) $=(1-$ Treatment parasitism/Control parasitism) $\times 100$ (Hassan 1985).

${ }^{\mathrm{d}}$ Bioassays 1 (sprayed pupae) and 2 (sprayed contact surface).

e Bioassays 3 (choice) and 4 (no-choice) with egg spraying.

Table 4 Effects of different entomopathogens on adults (bioassay 2) of Trichogramma pretiosum 1 and 5 days after the emergence (DAE) from treated eggs of the host Anagasta kuehniella.

\begin{tabular}{|c|c|c|c|c|}
\hline \multirow{2}{*}{$\begin{array}{l}\text { Treatment } \\
\text { a.i. } 100 \mathrm{~L}^{-1} \mathrm{H}_{2} \mathrm{O}\end{array}$} & \multicolumn{2}{|l|}{$1 \mathrm{DAE}^{\mathrm{a}}$} & \multicolumn{2}{|l|}{$5 \mathrm{DAE}^{\mathrm{a}}$} \\
\hline & Parasitism (\%) & Progeny viability (\%) & Parasitism (\%) & Progeny viability (\%) \\
\hline Water & $89.65 \pm 2.51 \mathrm{a}$ & $97.70 \pm 0.73 a$ & $94.20 \pm 5.80 \mathrm{a}$ & $96.81 \pm 1.90 \mathrm{a}$ \\
\hline AgMNPV $1.4 \times 10^{11} \mathrm{PIB}$ & $94.67 \pm 2.20 \mathrm{a}$ & $94.20 \pm 1.20 \mathrm{a}$ & $89.64 \pm 7.20 \mathrm{a}$ & $96.23 \pm 1.50 \mathrm{a}$ \\
\hline B. thuringiensis var. kurstaki $9.6 \times 10^{9} \mathrm{IU}$ & $88.56 \pm 3.57 a$ & $94.80 \pm 0.60 \mathrm{a}$ & $88.24 \pm 4.66$ a & $98.80 \pm 0.85 a$ \\
\hline B. thuringiensis var. aizawai $5 \times 10^{9} \mathrm{IU}$ & $93.20 \pm 3.82 a$ & $95.26 \pm 2.08 \mathrm{a}$ & $89.17 \pm 5.03 \mathrm{a}$ & $97.82 \pm 1.12 \mathrm{a}$ \\
\hline B. thuringiensis var. kurstaki $6.2 \times 10^{9} \mathrm{IU}$ & $86.54 \pm 2.36 \mathrm{a}$ & $96.24 \pm 1.41 \mathrm{a}$ & $88.31 \pm 4.30 \mathrm{a}$ & $96.75 \pm 2.08 \mathrm{a}$ \\
\hline B. bassiana $1 \times 10^{13}$ conidia & $91.36 \pm 3.12 \mathrm{a}$ & $94.14 \pm 1.89$ a & $85.91 \pm 6.16$ a & $97.22 \pm 0.80 \mathrm{a}$ \\
\hline M. anisopliae $1.6 \times 10^{12}$ conidia & $87.40 \pm 1.07 a$ & $95.12 \pm 0.87 a$ & $88.50 \pm 3.08 \mathrm{a}$ & $96.31 \pm 0.77 a$ \\
\hline T. harzianum $5 \times 10^{12}$ conidia & $88.04 \pm 4.22 \mathrm{a}$ & $95.36 \pm 2.04 \mathrm{a}$ & $84.45 \pm 3.82 \mathrm{a}$ & $95.93 \pm 1.53 \mathrm{a}$ \\
\hline Chlorpyrifos $240 \mathrm{~g}$ & $0.00 \pm 0.00 \mathrm{~b}$ & - & $0.00 \pm 0.00 \mathrm{~b}$ & - \\
\hline CV (\%) & 8.1 & 3.46 & 13.01 & 3.08 \\
\hline$F$ & 108.59 & 0.62 & 42.16 & 0.49 \\
\hline$P$ & $<0.0001$ & 0.7349 & $<0.0001$ & 0.83 \\
\hline$D F_{\text {residual }}$ & 34 & 31 & 33 & 30 \\
\hline
\end{tabular}

${ }^{a}$ Means \pm SEM in each column followed by the same letter did not differ from each other according to the Tukey test ( $5 \%$ probability). 
Table 5 Parasitism (\%) of eggs of the host Anagasta kuehniella treated with entomopathogens by Trichogramma pretiosum 1 and 5 days after host treatment and parasitoid progeny viability (\%) in free-choice tests (bioassay 3 ).

\begin{tabular}{|c|c|c|c|c|}
\hline \multirow{2}{*}{$\begin{array}{l}\text { Treatment } \\
\text { a.i. } 100 \mathrm{~L}^{-1} \mathrm{H}_{2} \mathrm{O}\end{array}$} & \multicolumn{2}{|l|}{1 DAS } & \multicolumn{2}{|l|}{5 DAS } \\
\hline & Parasitism (\%) ${ }^{a}$ & Progeny viability (\%) & Parasitism (\%) & Progeny viability $(\%)^{\mathrm{a}}$ \\
\hline Water & $90.1 \pm 0.9$ a & $95.0 \pm 0.6 \mathrm{a}$ & $81.0 \pm 4.2 \mathrm{a}$ & $95.0 \pm 0.7 \mathrm{a}$ \\
\hline AgMNPV $1.4 \times 10^{11} \mathrm{PIB}$ & $88.4 \pm 1.3$ a & $91.8 \pm 1.1 \mathrm{~b}$ & $70.5 \pm 3.3$ a & $95.3 \pm 1.0$ a \\
\hline $\mathrm{CV}$ & 2.84 & 2.06 & 10.05 & 1.87 \\
\hline Water & $87.9 \pm 2.6 \mathrm{a}$ & $92.4 \pm 2.1 \mathrm{a}$ & $80.8 \pm 4.3 \mathrm{a}$ & $93.2 \pm 2.3$ a \\
\hline B. thuringiensis var. kurstaki $9.6 \times 10^{9}$ IU & $85.8 \pm 1.1 \mathrm{a}$ & $90.9 \pm 2.0 \mathrm{a}$ & $75.3 \pm 0.5 \mathrm{a}$ & $94.1 \pm 4.6$ a \\
\hline CV & 5.16 & 4.98 & 8.63 & 6.66 \\
\hline Water & $89.3 \pm 2.4 \mathrm{a}$ & $93.7 \pm 1.1 \mathrm{a}$ & $83.7 \pm 1.8 \mathrm{a}$ & $95.2 \pm 2.0 \mathrm{a}$ \\
\hline B. thuringiensis var. aizawai $5 \times 10^{9}$ IU & $87.2 \pm 2.1 \mathrm{a}$ & $93.2 \pm 0.4 \mathrm{a}$ & $82.1 \pm 2.6 \mathrm{a}$ & $96.0 \pm 2.4 \mathrm{a}$ \\
\hline CV & 5.74 & 1.67 & 5.35 & 4.64 \\
\hline Water & $87.2 \pm 2.2 \mathrm{a}$ & $94.3 \pm 1.1$ a & $79.6 \pm 5.5$ a & $94.1 \pm 0.9$ a \\
\hline B. thuringiensis var. kurstaki $6.2 \times 10^{9} \mathrm{IU}$ & $88.3 \pm 2.8 \mathrm{a}$ & $94.0 \pm 1.4$ a & $72.3 \pm 7.6 \mathrm{a}$ & $88.4 \pm 4.2 \mathrm{a}$ \\
\hline $\mathrm{CV}$ & 6.54 & 2.98 & 17.55 & 6.69 \\
\hline Water & $91.9 \pm 1.0 \mathrm{a}$ & $94.5 \pm 0.8 \mathrm{a}$ & $78.5 \pm 3.8 \mathrm{a}$ & $95.5 \pm 1.5 \mathrm{a}$ \\
\hline B. bassiana $1 \times 10^{13}$ conidia & $91.9 \pm 2.0 \mathrm{a}$ & $93.8 \pm 0.5$ a & $82.1 \pm 6.3$ a & $90.5 \pm 2.2 \mathrm{a}$ \\
\hline $\mathrm{CV}$ & 3.88 & 1.63 & 11.30 & 3.48 \\
\hline Water & $87.1 \pm 2.0 \mathrm{a}$ & $92.8 \pm 0.8 \mathrm{a}$ & $82.2 \pm 2.5 \mathrm{a}$ & $95.0 \pm 1.1 \mathrm{a}$ \\
\hline M. anisopliae $1.6 \times 10^{12}$ conidia & $83.2 \pm 1.4 \mathrm{a}$ & $91.4 \pm 1.2 \mathrm{a}$ & $81.4 \pm 1.7$ a & $95.1 \pm 0.9$ a \\
\hline $\mathrm{CV}$ & 4.66 & 2.20 & 5.90 & 2.30 \\
\hline Water & $87.7 \pm 3.3 \mathrm{a}$ & $91.0 \pm 2.0 \mathrm{a}$ & $85.2 \pm 1.5$ a & $93.9 \pm 1.1 \mathrm{a}$ \\
\hline T. harzianum $5 \times 10^{12}$ conidia & $85.3 \pm 2.6 \mathrm{a}$ & $90.4 \pm 2.9$ a & $81.8 \pm 2.7$ a & $96.4 \pm 0.3$ a \\
\hline $\mathrm{CV}$ & 7.74 & 6.30 & 5.37 & 1.42 \\
\hline Water & $78.8 \pm 7.6 \mathrm{a}$ & $54.2 \pm 2.6 \mathrm{a}$ & - & - \\
\hline Chlorpyrifos $240 \mathrm{~g}$ & $1.7 \pm 1.7 \mathrm{~b}$ & $0.0 \pm 0.0 \mathrm{~b}$ & - & - \\
\hline CV & 26.80 & 6.52 & - & - \\
\hline
\end{tabular}

${ }^{a}$ Means \pm SEM in each column followed by the same letter for each comparison between sprayed and nonsprayed cards did not significantly differ from each other according to the $F$ test ( $5 \%$ probability).

Table 6 Parasitism (\%) of eggs of the host Anagasta kuehniella treated with entomopathogens by Trichogramma pretiosum 1 and 5 days after host treatment and parasitoid progeny viability (\%) in no-choice tests (bioassay 4 ).

\begin{tabular}{|c|c|c|c|c|}
\hline \multirow{2}{*}{$\begin{array}{l}\text { Treatment } \\
\text { a.i. } 100 \mathrm{~L}^{-1} \mathrm{H}_{2} \mathrm{O}\end{array}$} & \multicolumn{2}{|l|}{1 DAS } & \multicolumn{2}{|l|}{5 DAS } \\
\hline & Parasitism (\%) ${ }^{\mathrm{a}}$ & Progeny viability (\%) ${ }^{a}$ & Parasitism (\%) ${ }^{a}$ & Progeny viability (\%) ${ }^{\mathrm{a}}$ \\
\hline Water & $85.5 \pm 1.1 \mathrm{a}$ & $95.0 \pm 1.0 \mathrm{a}$ & $80.7 \pm 2.8$ a & $95.4 \pm 0.3$ a \\
\hline AgMNPV $1.4 \times 10^{11} \mathrm{PIB}$ & $87.2 \pm 0.8 \mathrm{a}$ & $97.6 \pm 0.8 \mathrm{a}$ & $81.2 \pm 5.1 \mathrm{a}$ & $97.6 \pm 0.6$ a \\
\hline B. thuringiensis var. kurstaki $9.6 \times 10^{9} \mathrm{IU}$ & $84.5 \pm 2.4 \mathrm{a}$ & $95.1 \pm 1.0 \mathrm{a}$ & $87.0 \pm 3.0 \mathrm{a}$ & $96.5 \pm 1.7$ a \\
\hline B. thuringiensis var. aizawai $5 \times 10^{9} \mathrm{IU}$ & $86.8 \pm 1.0 \mathrm{a}$ & $95.0 \pm 1.7$ a & $79.9 \pm 3.6$ a & $96.5 \pm 1.0 \mathrm{a}$ \\
\hline B. thuringiensis var. kurstaki $6.2 \times 10^{9} \mathrm{IU}$ & $85.8 \pm 2.0 \mathrm{a}$ & $95.0 \pm 0.8 \mathrm{a}$ & $85.9 \pm 2.1 \mathrm{a}$ & $96.0 \pm 0.8 \mathrm{a}$ \\
\hline B. bassiana $1 \times 10^{13}$ conidia & $86.1 \pm 1.8$ a & $93.6 \pm 0.9$ a & $81.0 \pm 3.5$ a & $94.8 \pm 2.0 \mathrm{a}$ \\
\hline M. anisopliae $1.6 \times 10^{12}$ conidia & $84.5 \pm 2.3 \mathrm{a}$ & $93.4 \pm 1.4 \mathrm{a}$ & $83.7 \pm 2.3$ a & $94.9 \pm 1.7$ a \\
\hline T. harzianum $5 \times 10^{12}$ conidia & $89.5 \pm 1.6 \mathrm{a}$ & $94.5 \pm 0.6 \mathrm{a}$ & $77.0 \pm 5.3$ a & $96.5 \pm 1.6 \mathrm{a}$ \\
\hline Chlorpyrifos $240 \mathrm{~g}$ & $0.0 \pm 0.0 \mathrm{~b}$ & - & $0.0 \pm 0.0 \mathrm{~b}$ & - \\
\hline $\mathrm{CV}$ & 4.82 & 2.60 & 10.18 & 2.74 \\
\hline$F$ & 302.75 & 1.41 & 69.44 & 0.60 \\
\hline$P$ & $<0.0001$ & 0.24 & $<0.0001$ & 0.75 \\
\hline$D F_{\text {residual }}$ & 36 & 31 & 32 & 28 \\
\hline
\end{tabular}

${ }^{\text {a }}$ Means \pm SEM in each column followed by the same letter did not differ from each other according to the Tukey test ( $5 \%$ probability). 
parasitism obtained by $F_{1}$ descendants of treated pupae indicates that ingestion may not have occurred or that it occurred at a nonlethal dose. Furthermore, viruses in general are very specific (Moscardi 1998), explaining the noted selectivity.

Parasitism and progeny viability (= emergence of adults) were unaffected by entomopathogens when parasitoids entered in direct contact by exposure to treated surfaces (bioassay 2). The observed bacterial and viral selectivity may be explained because the tested entomopathogens are only harmful to insects when ingested (Copping \& Menn 2000, Castro et al 1999). Ingestion of viruses or bacteria was unlikely because $T$. pretiosum adults walked on dry residues of the sprayed products. From all of the evaluated entomopathogens, only fungi can contaminate and infect insects by contact via conidia penetration through the insect cuticle (Alves 1998). Potrich et al (2009) observed mortality of $T$. pretiosum caused by $B$. bassiana and $M$. anisopliae by contact, although not at a significant rate, thus indicating that contamination and/or infection did not occur in our study or was insufficient to cause mortality of $T$. pretiosum adults.

Bioinsecticides may also influence the parasitoid host choice by modifying color, shape, odor, or behavior of the infected host, in addition to directly impact the insects (Magalhães et al 1998). In our study, parasitism and parasitoid progeny viability were not affected by the entomopathogens tested when evaluated in free- or no-choice tests. Only eggs sprayed with $1.4 \times 10^{11} \mathrm{PIB}$ AgMNPV in free-choice tests showed a reduced emergence of parasitoids than the control, although still higher than $90 \%$, which is above the minimum quality standard (85\%) of progeny viability (Navarro 1998). Therefore, this entomopathogen may still be considered selective to the parasitoid. These results indicate that host egg infection did not occur, even with a longer time period between spraying with an entomopathogen and parasitoid emergence, and therefore, no negative effect on $T$. pretiosum was found, similar to earlier reports (Potrich et al 2009).

The bioinsecticides $B$. anticarsia (Baculovirus $A E E^{\circledR}$ ), $B$. thuringiensis var. kurstaki (Thruricide $\left.{ }^{\circledast}\right), B$. thuringiensis var. aizawai $\left(\right.$ Agree $\left.^{\circledR}\right)$, B. thuringiensis var. kurstaki (Dipel $\left.{ }^{\circledR}\right)$, B. bassiana (Boveril ${ }^{\circledR}$ ), M. anisopliae (Metarril ${ }^{\circledR}$ ), and $T$. harzianum (Trichodermil ${ }^{\circledR}$ ) can be classified as selective to T. pretiosum pupae and adults, which is an indication that they may be used in conjunction with egg parasitoids without major negative effects on the studied parasitoid. In contrast, the insecticide chlorpyrifos is harmful, as it causes high mortality and it negatively affects the behavior of $T$. pretiosum in free-choice tests. Therefore, its use in IPM should be avoided and should be replaced by a more selective product to natural enemies whenever possible.
Acknowledgments The authors would like to thank Dagmar Frisch and an Editage editor for the English revision of this manuscript. Thanks are also extended to Embrapa Soja, the "Coordenação de Aperfeiçoamento de Pessoal de Nível Superior (CAPES)," and the "Conselho Nacional de Desenvolvimento Científico e Tecnológico" (CNPq), grant number $301420 / 2012-2$, for funds that supported this research. This paper was approved for publication by the Editorial Board of Embrapa Soybean as manuscript number $18 / 2014$.

\section{References}

Alves SB (1998) Fungos entomopatogênicos. In: Alves SB (ed) Controle Microbiano de Insetos. FEALQ, Piracicaba, pp 289-382

Bueno AF, Bueno RCOF, Parra JRP, Vieira SS (2008) Effects of pesticides used in soybeans crops to the egg parasitoid Trichogramma pretiosum. Cienc Rural 38:1495-1503

Bueno AF, Batistela MJ, Bueno RCOF, França-Neto JB, Nishikawa MAN, Filho AL (2011) Effects of integrated pest management, biological control and prophylactic use of insecticides on the management and sustainability of soybean. Crop Prot 30:937-945

Burr IW, Foster LA (1972) A test for equality of variances. Mimeo series no. 282. University of Purdue, West Lafayette

Carmo EL, Bueno AF, Bueno RCOF (2010) Pesticide selectivity for the insect egg parasitoid Telenomus remus. Biocontrol 55:455-464

Castro MEB, Souza ML, Sihler W, Rodrigues JCM, Ribeiro BM (1999) Biologia molecular de baculovírus e seu uso no controle de pragas no Brasil. Pesq Agrop Brasileira 34:1733-1761

Cônsoli FL, Rossi MM, Parra JRP (1999) Developmental time and characteristics of the immature stages of Trichogramma galloi and T. pretiosum (Hymenoptera, Trichogrammatidae). Rev Bras Entomol 43:271-275

Copping LG, Menn JJ (2000) Review biopesticides: a review of their action, applications and efficacy. Pest Manag Sci 56:651-676

El-Katatny MH (2010) Virulence potential of some fungal isolates and their control-promise against the Egyptian cotton leaf worm, Spodoptera littoralis. Arch Phytopathol Plant Protect 43:332-356

Ganassi S, Altomare C, Sabatini MA (2009) Interactions between fungi belonging to the genus Trichoderma and Myzus persicae (Hemiptera: Aphidoidea) to open new perspectives of biological control. Micol Ital 38:3-9

Glare TR, O'Callaghan M (2000) Bacillus thuringiensis: biology, ecology and safety. Wiley, Chichester, p 350

Hassan SA (1992) Guideline for the evaluation of side-effects of plant protection product on Trichogramma cacoeciae. In: Hassan SA (ed) Guidelines for testing the effects of pesticides on beneficial organisms: description of test methods. IOBC/WPRS Bull 15:18-39

Hassan SA, Bigler F, Blaisinger $P$, Bogenschutz $H$, Brun J, Chiverton $P$, Dickler E, Easterbrook MA, Edwards PJ, Englert WD, Firth SL, Huang $P$, Inglesfield C, Klingauf F, Kuhner C, Ledieu MS, Naton E, Oomen PA, Overmeer WPJ, Plevoets P, Reboulet JN, Rieckmann W, SamsoePetersen L, Shires SW, Staubli A, Stevenson J, Tuset JJ, Vanwetswinkel G, Van Zon AQ (1985) Standard methods to test the side-effects of pesticides on natural enemies of insects and mites developed by the IOBC/WPRS working group 'Pesticides and Beneficial Organisms'. EPPO Bull 15:214-255

Hoffmann-Campo CB, Oliveira LJ, Moscardi F, Gazzoni DL, CorrêaFerreira BS, Lorini IA (2003) Integrated pest management in Brazil. In: Maredia KM, Dakouo D, Mota-Sanches D (eds) Integrated pest management in the global arena. CABI, Wallingford, pp 285-299

Lomer CJ, Bateman RP, Jonhson DL, Labgewald J, Thomas MB (2001) Biological control of locusts and grasshoppers. Annu Rev Entomol 46: 667-702 
Magalhães BP, Monnerat R, Alves SB (1998) Interações entre entomopatógenos, parasitoides e predadores. In: Alves SB (ed) Controle Microbiano de Insetos, 2nd edn. FEALQ, Piracicaba, pp 195-216

Manzoni CG, Grützmacher AD, Giolo FP, Härter WR, Castilhos RV, Paschoal MDF (2007) Seletividade de agroquímicos utilizados na produção integrada de maçã aos parasitóides Trichogramma pretiosum Riley e Trichogramma atopovirilia Oatan \& Platner (Hymenoptera: Trichogrammatidae). BioAssay 2(1). doi:10.14295/BA. v2.0.50

Melo IS (1998) Agentes microbianos de controle de fungos fitopatogênicos. In: Melo IS, Azevedo JL (eds) Controle Biológico, 1st edn. EMBRAPA, Jaguariúna, pp 17-67

Monnerat RS, Batista AC, Medeiros PT, Martins ES, Melatti VM, Praça LB, Dumas VF, Morinaga C, Demo C, Gomes ACM, Falcão R, Siqueira CB, Silva-Werneck JO, Berry C (2007) Screening of Brazilian Bacillus thuringiensis isolates active against Spodoptera frugiperda, Plutella xylostella and Anticarsia gemmatalis. Biol Control 41:291-295

Moscardi F (1998) Utilização de vírus entomopatogênicos em campo. In: Alves SB (ed) Controle Microbiano de Insetos. FEALQ, Piracicaba, pp 509-533

Navarro MA (1998) Trichogramma spp. Producción, uso y manejo em Colombia. Impretec Press, Guadalajara de Buga, p 176

Parra JRP (1997) Técnicas de criação de Anagasta kuehniella, hospedeiro alternativo para produção de Trichogramma. In: Parra JRP, Zucchi RA (eds) Trichogramma e o Controle Biológico Aplicado. FEALQ, Piracicaba, pp 170-225

Parra JRP, Zucchi RA (2004) Trichogramma in Brazil: feasibility of use after twenty years of research. Neotrop Entomol 33:271-281
Pinto JD (1997) Taxonomia de Trichogrammatidae (Hymenoptera) com ênfase nos gêneros que parasitam Lepidóptera. In: Parra JRP, Zucchi RA (eds) Trichogramma e o Controle Biológico Aplicado. FEALQ, Piracicaba, pp 35-142

Potrich M, Alves LFA, Haas J, Silva ERL, Daros A, Pietrowski V, Neves PMOJ (2009) Seletividade de Beauveria bassiana e Metarhizium anisopliae a Trichogramma pretiosum Riley (Hymenoptera: Trichogrammatidae). Neotrop Entomol 38:822-826

Rampelotti FT, Ferreira A, Prando HF, Grutzmacher AD, Martins JFS, Tcacenco FA, Mattos MLT (2007) Patogenicidade de Metarhizium anisopliae (Metsch.) Sorokin sobre as fases do desenvolvimento de Timbraca limbativentris (Stal) (Hemiptera: Pentatomidae) em condições de laboratório. Arq Inst Biol 74:141-148

Samuels RI, Coracini DL, Santos CAM, Gava CAT (2002) Infection of Blissus antillus (Hemiptera: Lygaeidae) eggs by the entomopathogenic fungi Metarhizium anisopliae and Beauveria bassiana. Biol Control 23: 269-273

SAS Institute (2001) SAS user's guide: statistics, version 8e. SAS Institute, Cary

Shapiro SS, Wilk MB (1965) An analysis of variance test for normality. Biometrika 52:591-611

Van Den Bosch R, Messenger PS, Gutierrez AP (1982) An introduction to biological control. Plenum, New York, p 358

Van Lenteren JC, Bueno VHP (2003) Augmentative biological control of arthropods in Latin America. Biocontrol 48:123-139

Veena-Bhamrah HS (2007) Studies on pathogenicity and management of mole cricket, Gryllotalpa gryllotalpa. Ann Plant Prot Sci 15:381-383 